\title{
Oil Generation in the Michigan Basin: A biological marker and carbon isotope approach
}

\author{
JÜrgen Rullkötter ${ }^{1}$, Philip A. Meyers ${ }^{2}$, Rainer G. Schaefer ${ }^{1}$ and Keith W. Dunham ${ }^{2}$ \\ 'Institute of Petroleum and Organic Geochemistry (ICH-5), KFA-Jülich GmbH, P.O. Box 1913, \\ D-5170 Jülich 1, F.R.G. \\ ${ }^{2}$ Department of Atmospheric and Oceanic Science, University of Michigan, Ann Arbor, U.S.A.
}

(Received 17 October 1985; accepted 12 March 1986)

\begin{abstract}
Palaeozoic strata in the Michigan Basin produce crude oils which, despite their rather small volume and economic value, are interesting because of the considerable age of the basin and because of the opportunity to study generation and migration of oils within a relatively simple but ancient geological setting.

Based on $n$-alkane profiles, biological marker distributions and carbon isotope ratios, the oils belong to three main families of different genetic origin and a few less important mixed types. Silurian oils from Salina and Niagara Limestones have broad $n$-alkane distributions and abundant isoprenoid hydrocarbons. A strong phytane-over-pristane predominance and the lack of diasteranes indicate a carbonate source for these oils. Chemical maturity parameters show that they are more mature than the oils from the other main families from which they are also clearly distinguished by carbon isotope ratios of hydrocarbon fractions and single $n$-alkanes.

Oils found in the calcareous Ordovician Trenton formation contain $n$-alkane, cyclohexylalkane and alkyl phenanthrene distributions typical of immature oils. Many oils from the Devonian Dundee reservoirs are very similar in overall composition to the Trenton oils.

Devonian Traverse oils are considered to be mainly from a Devonian source with some contribution of Ordovician-type oil and are of intermediate maturity. Based on calculations using kinetic parameters of biological marker reactions, considerably deeper subsidence of the Devonian source rock in the past is implied.
\end{abstract}

Key words: carbon isotopes, chemical maturity parameters, cyclohexylalkanes, methylphenanthrenes, Michigan Basin, $n$-alkanes, oil/oil correlation, Palaeozoic crude oils, sterane isomerization, steroid aromatization

\section{INTRODUCTION}

Petroleum is produced from Palaeozoic strata in the Michigan Basin. Some of the important reservoir formations include the Stray Sandstone (Mississippian), the Berea Sandstone, Traverse Limestone, and Dundee Limestone (Devonian), the Salina and Niagara Limestone (Silurian), and the Trenton and Black River Limestones (Ordovician). Michigan Basin oils are interesting despite their rather small volume and economic value, because of the considerable age of the basin and because of the opportunity to study generation and migration of oils within a relatively simple but ancient geological setting.

\section{The Michigan Basin}

The geology of the Michigan Basin was described in detail by Dorr and Eschman (1970) and has been recently summarized by Nunn and Sleep (1984), and Nunn et al. (1984). The basin is intracratonic and consists of several kilometers of gently dipping, shallow water sediments. Its shape is nearly circular (Fig. 1). Although some Cambrian and Mesozoic strata exist, nearly all of the sediments in the Michi-

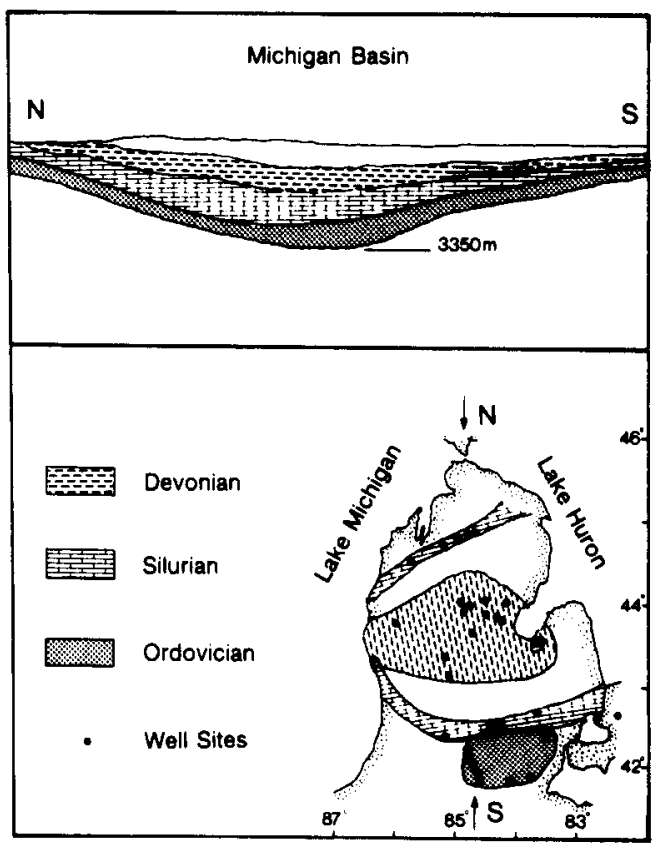

Fig. 1. North-South cross section of the Michigan Basin and location map showing principal production zones from reservoirs of different ages (from Vogler et al., 1981). 


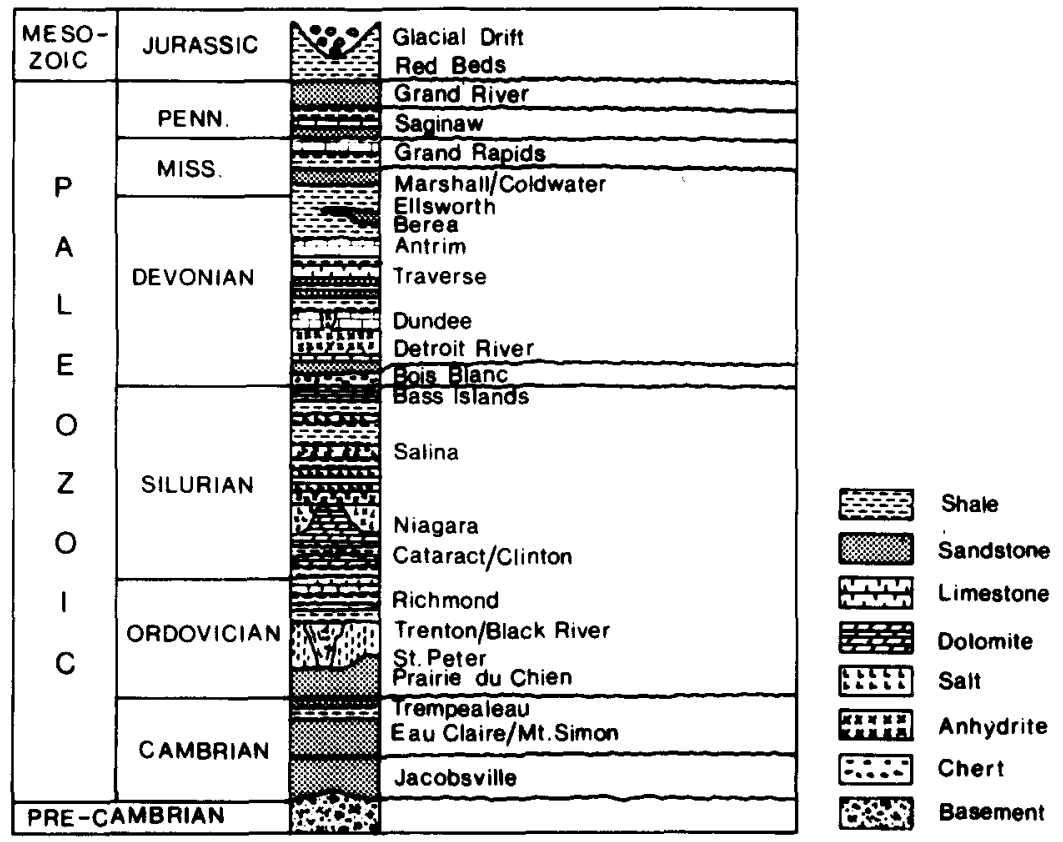

Fig. 2. Schematic stratigraphic column of the Michigan Basin (modified after Labo et al., 1981, using information from McCullan and Slaughter, 1964).

gan Basin are Ordovician, Silurian and Devonian in age, with only small amounts of late Palaeozoic and early Mesozoic deposits (Fig. 2). Limestone and dolomite are the predominant lithologies. Sandstone and shale are subordinate, but evaporites are common in the Silurian (Cohee and Landes, 1958). There is a lack of secondary structural deformation of the sediments, but extensive unconformities exist at the base of the middle Ordovician, in the late Silurian, and at the end of the Devonian (Sleep and Sloss, 1978).

There remain important questions about the thermal history of the Michigan Basin, and these bear directly upon petroleum generation. The present geothermal gradient appears to be low. Sleep and Sloss (1978) give a figure of about $21^{\circ} \mathrm{C} / \mathrm{km}$ obtained from a deep borehole near the center of the basin which penetrated into the Precambrian basement. Given the relatively shallow maximum depth of the sedimentary rocks within the basin (less than $4300 \mathrm{~m}$; less than $3500 \mathrm{~m}$ for the basin sediments proper of middle Ordovician and younger age; Fig. 1), the amount of heat flow into the sediments limits petroleum generation to late Silurian and older rocks (Meyers and Moore, 1983; Nunn and Sleep, 1978). Other reconstructions of the thermal history of this basin more severely limit petroleum formation to Ordovician strata and only the most deeply buried Silurian sediments (Nunn et al., 1984, 1985), although this has recently been critically debated by Daly and Lilly (1985). In contrast, Cercone (1984) concludes from the interpretation of visual maturity data of kerogen in Palaeozoic rocks and of Pennsylvanian coals that thermal gradients were once as high as $45^{\circ} \mathrm{C} / \mathrm{km}$ and that as much as $1 \mathrm{~km}$ of Carboniferous sediments was eroded prior to late Jurassic times, permitting oil generation to occur in Devonian rocks during the Palaeozoic.

\section{Oils of the Michigan Basin}

Simple geochemical comparisons using $n$-alkane distributions have been adequate to show that Ordovician Trenton-Black River oils and a number of Devonian Dundee oils are very similar, whereas Silurian Niagara-Salina oils form a distinct family (Vogler et al., 1981). Differences of other Devonian oils (e.g. Traverse and Detroit River) were explained to reflect separate sources (Illich and Grizzle, 1983) or mixing of Silurian and Ordovician oils (Pruitt, 1983). A similar classification of oils from the Ontario part of the Michigan Basin has recently been published by Powell et al. (1984).

\section{Objectives}

The present study focuses on a more detailed compositional characterization of the Michigan Basin crude oils using biological marker and stable carbon isotope methods. The data so generated were intended to be the basis for a refined classification of the oils into genetic families, a detection of possible mixing of oils from different sources, and an assessment of the thermal maturities of the oils. They should further provide information allowing a contribution to the reconstruction of oil generation and migration in the Michigan Basin based on crude oil composition. A series of rock samples available for this study turned out to have little or no source rock characteristics (Dunham et al., 1986) and will not be discussed here. 


\section{EXPERIMENTAL}

Stable carbon isotope ratios were determined on whole oils and on oil fractions using a VG Micromass 602 mass spectrometer calibrated with NBS-20 (carbonate), NBS-21 (graphite) and NBS-22 (petroleum) standards. Data have been corrected for ${ }^{17} \mathrm{O}$ and are presented relative to the PDB standard. The oil fractions for isotope analysis were obtained by column chromatography on an alumina over silica gel column. The aliphatic hydrocarbon fraction was eluted with petroleum ether, the aromatic hydrocarbons with petroleum ether:benzene $(85: 15)$ and the fraction containing resins plus asphaltenes with dichloromethane.

Crude oil fractions for gas chromatography (GC) and gas chromatography-mass spectrometry (GC-MS) investigations were obtained by the method of Radke et al. (1980). Instrumental parameters for GC and GC-MS analysis have been described by Rullkötter et al. (1985) except that a VG 7070 E mass spectrometer under Kratos DS55C data system control was used. Light hydrocarbon analysis of the oils was performed according to the technique of Schaefer et al. (1978).

\section{RESULTS AND DISCUSSION}

\section{Bulk composition}

Among the thirty crude oils studied, those from the Stray Sandstone (No. 2), the Dundee Limestone in the Crystal Field (No. 104) and the Trenton-Black River Limestone in the Albion-Scipio Field (No. 4) are biodegraded (cf. Table 1 for oil numbers); depletion of light hydrocarbons in a few other oils may be due to incipient biodegradation or physicial separation in the subsurface or during storage and handling. One of the Silurian oils (No. 26, Chester 15 Field) is a light condensate with $98.5 \%$ evaporation loss (Table 1), whereas the Pennfield Field oil (No. 17) has an unusual bulk composition among the Silurian samples because it obviously contains asphaltic material very similar to Thornton bitumen (based on the abundance and composition of the biological markers) which is found in the Silurian Niagara dolomite in near-by northern Illinois (Rullkötter and Philp, 1981).

With exceptions related to the effects described above, all Michigan Basin oils conspicuously contain high proportions of total hydrocarbons ranging between about 70 and $90 \%$ (Table 1). The Silurian oils reach the highest values and are followed by the Ordovician oils, whereas the Devonian Dundee and Detroit River oils have lower relative hydrocarbon

Table 1: Bulk and stable carbon isotope composition of crude oils from the Michigan Basin. (n.d. = not determined)

\begin{tabular}{|c|c|c|c|c|c|c|c|c|c|c|c|c|c|}
\hline \multirow{2}{*}{ No. } & \multirow{2}{*}{ Reservoir Fm. } & \multirow{2}{*}{ Field } & \multirow{2}{*}{ Depth $(f t)$} & \multirow{2}{*}{$\begin{array}{l}\text { Evapor } \\
\text { loss }(\%)\end{array}$} & \multicolumn{5}{|c|}{ Liquid chromatography fractions (\%) } & \multicolumn{4}{|c|}{$\delta^{13} \mathrm{C}(\%$} \\
\hline & & & & & Sat. he & Arom. he & NSO & Asph. & Insol. & Whole oil & Sat. nc & Arom. he & Res./asph. \\
\hline 2 & Stray Ss. & Clare & $1301-1306$ & 19.5 & 45.2 & 26.7 & 169 & 10.9 & 0.3 & -30.1 & -30.5 & -29.6 & -30.1 \\
\hline 5 & Berea Ss. & Saginaw & 1826 & 39.4 & 55.9 & 27.5 & 10.4 & 5.9 & 0.3 & -31.9 & -32.0 & -30.8 & -30.5 \\
\hline 35 & Traverse Ls. & Peacock & & 30.5 & 63.3 & 24.9 & 7.0 & 4.5 & 0.3 & -29.3 & -29.4 & -28.7 & -28.4 \\
\hline 34 & Traverse Ls. & Stanton & $2895-2907$ & 45.7 & 57.1 & 24.7 & 10.4 & 4.8 & 0.3 & & & & \\
\hline 9 & Dundee Ls. & Bentley & $3503-3543$ & 36.4 & 49.9 & 28.6 & 20.5 & 0.6 & 0.4 & -29.1 & -29.0 & -28.9 & -29.3 \\
\hline 12 & Dundee Ls. & N. Adams & $2876-2884$ & 24.7 & 41.2 & 26.2 & 26.0 & 6.0 & 0.6 & -29.6 & -29.2 & -29.6 & -29.7 \\
\hline 104 & Dundee Ls. & Crystal & $3178-3184$ & 4.4 & 57.9 & 25.7 & 7.7 & 8.4 & 0.3 & -27.5 & -27.4 & -27.7 & -27.5 \\
\hline 105 & Dundee Ls. (?) & Oil Springs & & 13.3 & 49.7 & 21.9 & 14.2 & 13.7 & 0.5 & -30.2 & -30.4 & -30.1 & n.d. \\
\hline 8 & Dundee Ls. & Bentley & $3523-3550$ & 44.3 & 45.7 & 30.8 & 19.5 & 4.1 & 0.1 & & & & \\
\hline 25 & Dundee Ls. & Rosebush & $3693-3709$ & 35.7 & 58.4 & 24.3 & 14.9 & 2.0 & $<0.1$ & & & & \\
\hline 27 & Dundee Ls. & N. Buckeye & $3558-3663$ & 35.7 & 43.4 & 31.5 & 22.3 & 2.2 & 0.1 & & & & \\
\hline 7 & Detroit River Ls. & Hamilton & $5205-5312$ & 38.9 & 57.9 & 19.9 & 17.2 & 5.0 & 0 & & & & \\
\hline 6 & Detroit River Sour Ls. & Skeels & $\begin{array}{l}4847-4855 \\
5056-5085\end{array}$ & 39.9 & 56.6 & 23.2 & 10.6 & 9.9 & 0.4 & & & & \\
\hline 11 & Detroit River Sour Ls. & S. Buckeye & $4481-4512$ & 39.7 & 48.7 & 27.4 & 7.7 & 15.7 & 0.5 & -29.1 & -29.2 & -28.5 & -28.5 \\
\hline 13 & Niagaran Salina Ls. & Onondaga 10 & $3850-3870$ & 41.0 & 73.1 & 17.6 & 9.0 & 0.2 & $<0.1$ & & & & \\
\hline 1 & Niagaran Salina Ls. & Vevay 16 & $\begin{array}{l}4165-4179 \\
4202-4204\end{array}$ & 52.8 & 67.0 & 23.8 & 8.8 & 0 & 0 & & & & \\
\hline 17 & Niagaran Ls. & Pennfield & $\begin{array}{l}2695-2699 \\
2704-2722\end{array}$ & 16.3 & 33.1 & 30.4 & 30.4 & 6.0 & $<0.1$ & -28.3 & -29.3 & -27.6 & -27.5 \\
\hline 33 & Niagara Ls. & Carleton 4 & $4766-4882$ & 40.0 & 69.5 & 17.4 & 6.7 & 6.2 & $<0.1$ & & & & \\
\hline 26 & Niagara Ls. & Chester 15 & $5930-6278$ & 98.5 & 66.1 & 10.4 & 13.7 & 0 & 0 & & & & \\
\hline 21 & Niagara Ls. & Blue Lake & & 38.7 & 72.6 & 19.1 & 7.4 & $<0.1$ & 0.8 & -29.1 & -29.6 & -27.0 & -27.6 \\
\hline 15 & Niagara Ls. & Grant 26 & & 40.5 & 67.2 & 19.9 & 11.8 & 0.3 & $<0.1$ & -29.2 & -29.7 & -27.3 & -30.0 \\
\hline 107 & Niagara Ls. & Rapid River 27 & & 55.3 & 69.0 & 20.5 & 8.7 & 1.5 & $<0.1$ & & & & \\
\hline 14 & Trenton Ls. & Albion-Scipio & $4156-4160$ & 31.9 & 62.7 & 23.6 & 13.4 & $<0.1$ & 0.2 & -29.0 & -29.5 & -28.6 & -28.7 \\
\hline 24 & Trenton Ls. & Deertield & $2113-2160$ & 40.4 & 69.3 & 21.3 & 9.2 & $<0.1$ & $<0.1$ & -28.4 & -28.5 & -28.2 & -31.4 \\
\hline 30 & Trenton Ls. & Blissfield & $2686-2727$ & 12.5 & 73.0 & 16.0 & 4.8 & 5.4 & 0.8 & -28.8 & -28.7 & -28.0 & -30.4 \\
\hline 109 & Trenton Ls. & Fortuna & 4535 & 35.4 & 45.8 & 29.8 & 25.1 & 0.7 & $<0.1$ & & & & \\
\hline 19 & Trenton-Black River Ls. & Northville & $\begin{array}{l}4262-4290 \\
4320-4374\end{array}$ & 16.6 & 67.1 & 22.1 & 10.6 & $<0.1$ & $<0.1$ & & & & \\
\hline 18 & Trenton-Black River Ls. & Hannover & $4368-4375$ & 23.2 & 66.7 & 18.5 & 5.3 & 9.0 & 0.5 & -28.9 & -29.0 & -28.1 & -31.0 \\
\hline 4 & Trenton-Black River Ls. & Albion-Scipio & $3919-3924$ & 34.5 & 60.8 & 26.1 & 11.8 & 0.6 & 0.1 & & & & \\
\hline 32 & Black River Ls. & Albion-Scipio & $4770-4812$ & 34.0 & 67.1 & 24.0 & 7.9 & 0.6 & 0.1 & & & & \\
\hline 108 & Black River Ls. & Albion-Scipio & $\begin{array}{l}4196-4206 \\
4168-4178\end{array}$ & n.d. & n.d. & n.d. & n.d. & n.d & n.d. & n.d. & -28.7 & -28.6 & -28.8 \\
\hline
\end{tabular}


concentrations. The same sequence also applies to the saturated hydrocarbon contents. With few exceptions, asphaltene contents are high only in oils from Devonian and younger reservoirs.

\section{Stable carbon isotopes}

The plot of $\delta^{13} \mathrm{C}$ values of the aliphatic and aromatic hydrocarbon fractions of the oils examined in this study shows several features (Fig. 3). Foremost among these is that Silurian oils group closely together, and their isotopic composition according to Sofer (1984) characterizes oils that have sources dominated by terrigenous organic matter. The Devonian and Ordovician oils separate from the Silurian grouping, and their carbon isotopes indicate marine organic matter origins. This difference in source character was earlier suggested by Vogler et al. (1981) in $n$-alkane distributions and in isotopic signatures of individual $n$-alkanes of representative Michigan Basin oils.

Ordovician oils tend to have slightly heavier aliphatic and aromatic fractions than do the oils in the Devonian and younger reservoirs (Fig. 3). This difference may indicate that the Ordovician oils are somewhat more thermally mature than the Devonian samples (Lewan, 1983; Mackenzie et al., 1986). The oil from the Berea Sandstone is isotopically the lightest which would be consistent with an early migration from the source rock; major compositional differences (see below) indicate that a lower maturity only may not be a sufficient explanation for the more negative carbon isotope values of the Berea oil relative to the Dundee Limestone oils in Fig. 3. One Devonian oil, from the Crystal field (No. 104) which produces from the Dundee Formation, and the Stray Sandstone oil (No. 2) are isotopically heavier, particularly in the saturated hydrocarbon fraction, than other oils they are compositionally related to, i.e. Dundee oils and Berea oil, respectively (Fig. 3; Table 1). The gas chromatograms of these two oils suggest that they have experienced biodegradation, and the

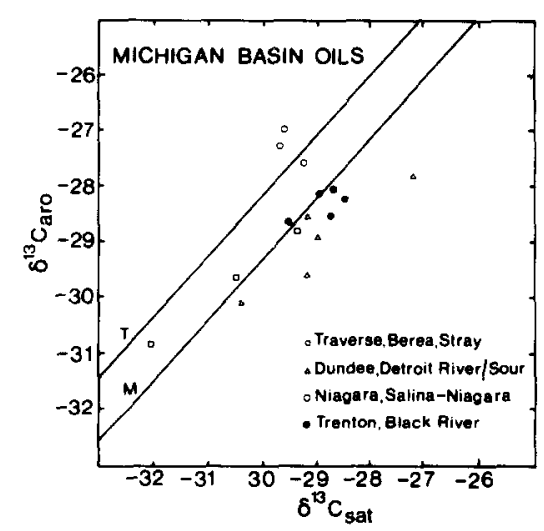

Fig. 3. $\delta^{13} \mathrm{C}$ of aliphatic hydrocarbons vs $\delta^{13} \mathrm{C}$ of aromatic hydrocarbons for crude oils from the Michigan Basin. Solid lines are trend lines for terrigenous (T) and marine (M) crude oils according to Sofer (1984). isotopic composition is consistent with the changes that could occur through microbial attack (Stahl, 1980).

A comparison of $\delta^{13} \mathrm{C}$ values of whole oils and their three fractions for individual Ordovician, Silurian and Devonian oils (Table 1) shows that the signatures of the whole oil, saturated, and aromatic hydrocarbons have similar patterns in Ordovician and Devonian oils, but the resin-asphaltene values of three of the five Ordovician oils are markedly different from the Devonian pattern. Because of the difference in the resin-asphaltene carbon isotope compositions and because two Ordovician oils from the same field (Albion-Scipio; Nos 14 and 108) are so similar in isotope values of this fraction, it is possible that secondary effects in the reservoir rock or during migration strongly influenced the resin-asphaltene fraction.

\section{Low-molecular-weight hydrocarbons}

For selected crude oils (see Table 2) the lowmolecular-weight hydrocarbon composition was determined by capillary gas chromatography. The Stray and Berea oils are relatively rich in branched and cyclic alkanes. The methylbutane $/ n$-pentane and 2 -methylpentane/ $n$-hexane ratios are above unity in the Stray oil. Benzene and toluene are only trace components and thus both samples, in particular the Stray oil, may be affected by biodegradation and/or water washing. The same also applies to the Traverse oil, but despite the trace concentrations of benzene and toluene there are no signs of biodegradation.

Both the Devonian Dundee and the Ordovician oils are very rich in $n$-alkanes resulting in high $n$-alkane/isoalkane concentration ratios. The Silurian oils are relatively rich in toluene as well as branched and normal alkanes. Cycloalkanes, except for methylcyclohexane, are minor components. The methylbutane $/ n$-pentane and 2-methylpentane/ $n$-hexane ratios are close to or above unity.

Low-molecular-weight hydrocarbon compositional parameters summarized in Table 2 appear to reflect both source controlled and maturity related properties. Following concepts of Thompson (1979), the samples with the highest "heptane-values" (parameter $G$ in Table 2) should be the most mature oils in this series, and these are the Dundee Limestone oils and one of the Ordovician Trenton oils (No. 14, Albion Scipio Field) with $G$ values of 49 and $42 \%$, respectively. This conclusion, however, is only partly confirmed by other maturity-sensitive parameters. The $n$-hexane/methylcyclopentane + 2,2-dimethylpentane concentration ratios (cf. Jonathan et al., 1975), the paraffin/naphthene ratios for $C_{6}$ and $C_{7}$ hydrocarbons, and the so-called "first paraffin index" of Thompson (which essentially is a $C_{7}$ branched alkane/cycloalkane concentration ratio) are partly contradictory to each other in terms of maturity indications. Some of these inconsistencies are certainly due to differences in the source material of the 
Table 2: Low-molecular-weight hydrocarbon parameters

\begin{tabular}{rllcllllll}
\hline No. & Reservoir Fm. & Field & Depth $(\mathrm{f})$ & G & I & E & U & V & A \\
\hline 2 & Stray Ss. & Clare & $1301-1306$ & 12 & 0.5 & 0.8 & 1.6 & 0.6 & 5.3 \\
5 & Berea Ss. & Seginaw & 1826 & 17 & 0.5 & 0.8 & 1.4 & 0.7 & 3.9 \\
35 & Traverse Ls. & Peacock & - & 26 & 0.7 & 1.3 & 1.4 & 0.9 & 4.8 \\
\hline 9 & Dundee Ls. & Bentley & $3303-3543$ & 49 & 1.5 & 3.2 & 2.0 & 1.7 & 3.8 \\
12 & Dundee Ls. & N. Adams & $2876-2884$ & 42 & 0.8 & 1.6 & 0.9 & 1.2 & 5.1 \\
\hline 13 & Niagaran Salina Ls. & Onondags 10 & $3850-3970$ & 28 & 4.1 & 2.8 & 4.3 & 2.4 & 4.0 \\
17 & Niagara Ls. & Pennfieid & $2695-2699$, & 26 & 2.3 & 1.7 & 3.3 & 2.0 & 5.3 \\
& & & $2704-2722$ & & & & & & \\
21 & Niagara Ls. & Btue Lake & - & 24 & 2.9 & 1.6 & 2.9 & 2.1 & 5.0 \\
15 & Niagara Ls. & Grani 26 & - & 31 & 4.3 & 3.8 & 5.4 & 2.8 & 3.3 \\
\hline 14 & Trenton Ls. & Albion-Scipio & $4156-4160$ & 42 & 1.6 & 3.2 & 2.2 & 1.6 & 3.1 \\
24 & Trenton Ls. & Deentield & $2113-2160$ & 30 & 1.7 & 2.5 & 1.9 & 1.3 & 3.5 \\
\hline
\end{tabular}

G = similar to 2nd paraffin index, "heptane-value" (Thompson 1979, slightly modified)

= similar to 1 st paraffin index (Thompson 1979, slightly moditied)

$E=$ n-hexane/methylcyclopentane + 2,2-dimethylpentane ratio (Jonathan et al., 1975, slightly modified)

$U=$ paraffin/naphthene ratio for $C_{6}$ hydrocarbons

$V$ = paraffin/naphthene ratio for $C_{7}$ hydrocarbons

R = trans/cis-1,2-dimethyicyclopentane ratio (Schaefer et al., 1984)

oils. The oils from the Silurian reservoirs for example, have extremely high paraffin/naphthene ratios, but only moderate "heptane-values".

The parameter " $R$ ", recently introduced as a maturity parameter for type-III organic matter (Schaefer et al., 1984), and believed to be less source-dependent than the other parameters in Table 2, leads to the conclusion that the Ordovician oil from the AlbionScipio Field (No. 14) is the most mature one. Values of less than 4.0 are encountered, however, also in the oils from the Berea Sandstone, the Dundee Limestone (No. 9, Bentley Field) and the Niagara Limestone (No. 12, Grant 26 Field). The least mature samples according to parameter " $R$ " would be oils No. 2 from the Stray Sandstone (biodegraded), No. 12 from the Dundee Limestone (N. Adams Field), and No. 17 from the Niagara Limestone (Pennfield Field). It should be remembered, however, that these oils may originate from marine organic matter, and hence parameter $R$ is untested for this kerogen type.

\section{Whole-oil hydrocarbon distributions}

As shown by Vogler et al. (1981), and Illich and Grizzle (1983), oils having the characteristic $n$-alkane pattern of Ordovician or older oils and rock extracts (Martin et al., 1963; McKirdy et al., 1983; Zumberge, 1983; Alexander et al., 1984; Fowler and Douglas, 1984; Reed et al., 1986) are found in Ordovician and Devonian (Dundee, Detroit River) reservoirs in the Michigan Basin. The two examples in Fig. 4 clearly show the conspicuous odd-carbon-number predominance of the $n$-alkanes below $n-\mathrm{C}_{20}$ in contrast to a smooth distribution of the (less abundant) longerchain $n$-alkanes. A common characteristic of oils of this type also is the unusually low relative concentration of isoprenoid hydrocarbons (e.g. pristane and phytane). In some of the Devonian oils the oddcarbon-number predominance is less pronounced than shown in Fig. 4. Slightly increased isoprenoid hydrocarbon and long-chain $n$-alkane abundances suggest mixing with a Traverse type oil in the case of a Dundee oil from the Oil Springs Field in Ontario (No. 105; may also be a regional anomaly, cf. Powell et al., 1984) and a Detroit River Sour oil from the S. Buckeye Field (No. 11) or with Silurian type oil in the case of two other Detroit River oils (Nos 6 and 7). This latter observation is consistent with the interpretation of Pruitt (1983).

The characteristic $n$-alkane and isoprenoid hydrocarbon composition of the Ordovician Trenton and Devonian Dundee oils should bear a close and specific relation to the type of organisms contributing to the organic matter in the source rock. Aquatic organisms usually contain only small amounts of saturated hydrocarbons, thus polar precursors are likely for the odd-numbered $n$-alkanes, e.g. fatty acids with up to 20 carbon atoms which would produce the odd-numbered $n$-alkanes by decarboxylation. The fatty acid composition of the Dundee oil from the Bentley Field is dominated by $\mathrm{C}_{16}$ and $\mathrm{C}_{18}$ saturated and monoolefinic fatty acids with moderate amounts of $\mathrm{C}_{12}, \mathrm{C}_{14}, \mathrm{C}_{15}$ and $\mathrm{C}_{20}$ acids, and smaller concentrations of higher homologues. This would be roughly consistent with the $n$-alkane distribution of this oil (Fig. 4, top) if the presence of a certain amount of $n$-alkanes from non-specific cracking is assumed. The low pristane and phytane concentrations imply that the precursor organisms are either non-photosynthetic and, if microorganisms are also considered main contributors of isoprenoids to the sediments (Risatti et al., 1984), that the microbial membranes mainly contained unbranched fatty acids with rigidifiers (if any) other than isoprenoids. The odd-carbon-number predominance of the $n$-alkanes of the Ordovician oil type finally suggests that the maturity of the organic matter at the time of hydro- 

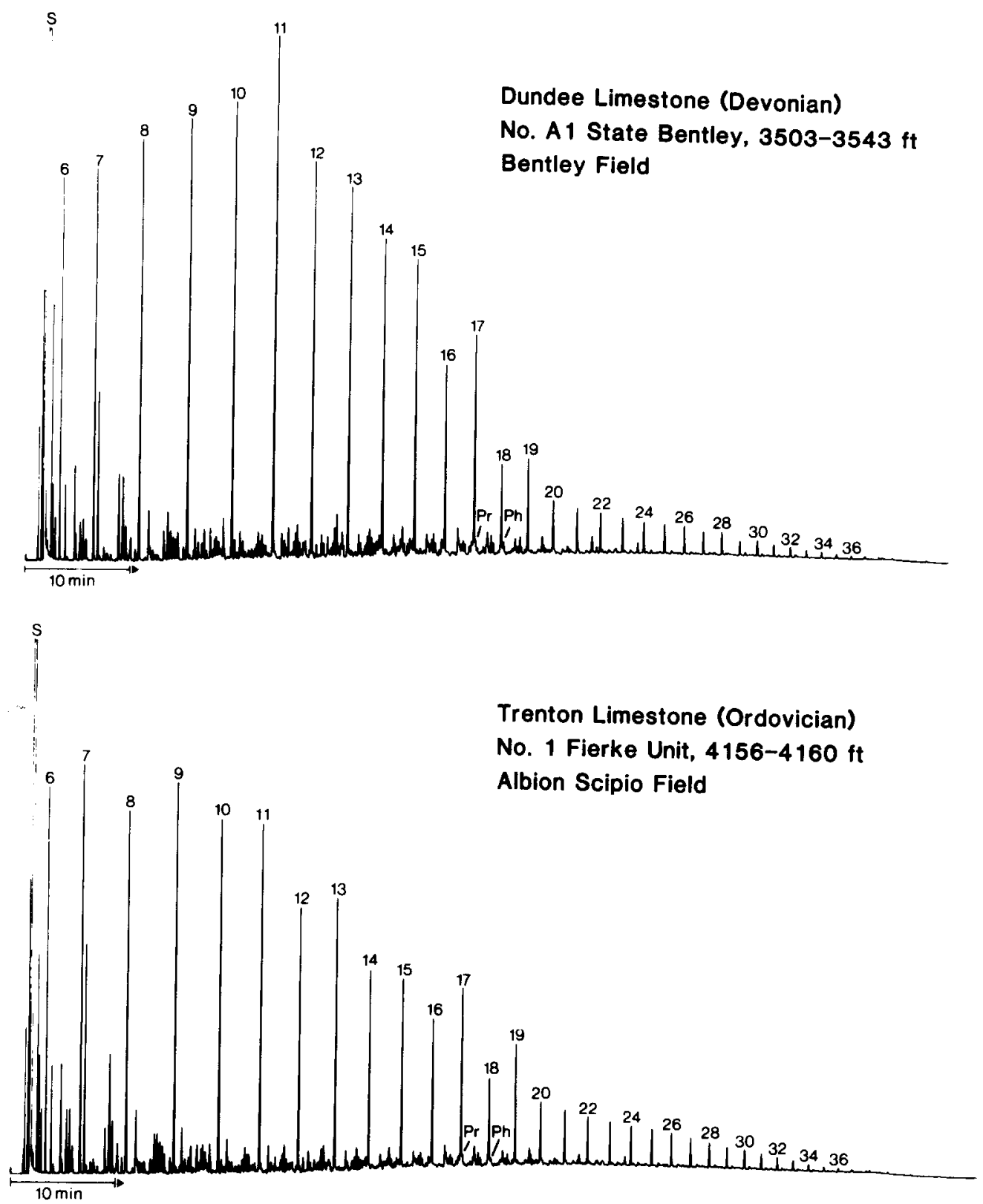

Fig. 4. Whole oil gas chromatograms of typical crude oils from Devonian Dundee Limestone and Ordovician Trenton Limestone reservoirs in the Michigan Basin. Numbers indicate $n$-alkanes; $\mathrm{Pr}=$ pristane; $\mathrm{Ph}=$ phytane.

carbon generation was relatively low and that generation occurred in a source rock catalyzing decarboxylation rather than reduction of fatty acids as a prominent reaction to form the $n$-alkanes. The same type of $n$-alkane distribution has been observed by Reed et al. (1986) after extraction or pyrolysis of mat-like stringers of organic matter within the Trenton Limestones.

The Traverse Limestone oil from the Peacock Field (Fig. 5, top) exhibits a hydrocarbon distribution commonly encountered for a normal mature crude oil from a clay-bearing source rock. In this respect, this oil is similar to the other Traverse oil investigated (No. 34) and the Berea (No. 5) and Stray (No. 2) oils.
All Silurian oils have a very broad $n$-alkane distribution like that of the Grant 26 Field sample in Fig. 5 (bottom). Coastal brackish higher plants are likely to have contributed to the long-chain $n$-alkanes (Attaway et al., 1970), but an influence of terrestrial plants is also possible (Eglinton and Hamilton, 1963); this certainly limits the age of the source rock to the Silurian. The pronounced phytane predominance over pristane suggests generation of the Silurian oils in a source rock deposited under strongly reducing conditions (probably carbonate or evaporite) despite the odd-over-even predominance of the long-chain $n$-alkanes which probably are directly derived from the living organisms. Some of the Silurian oils show 

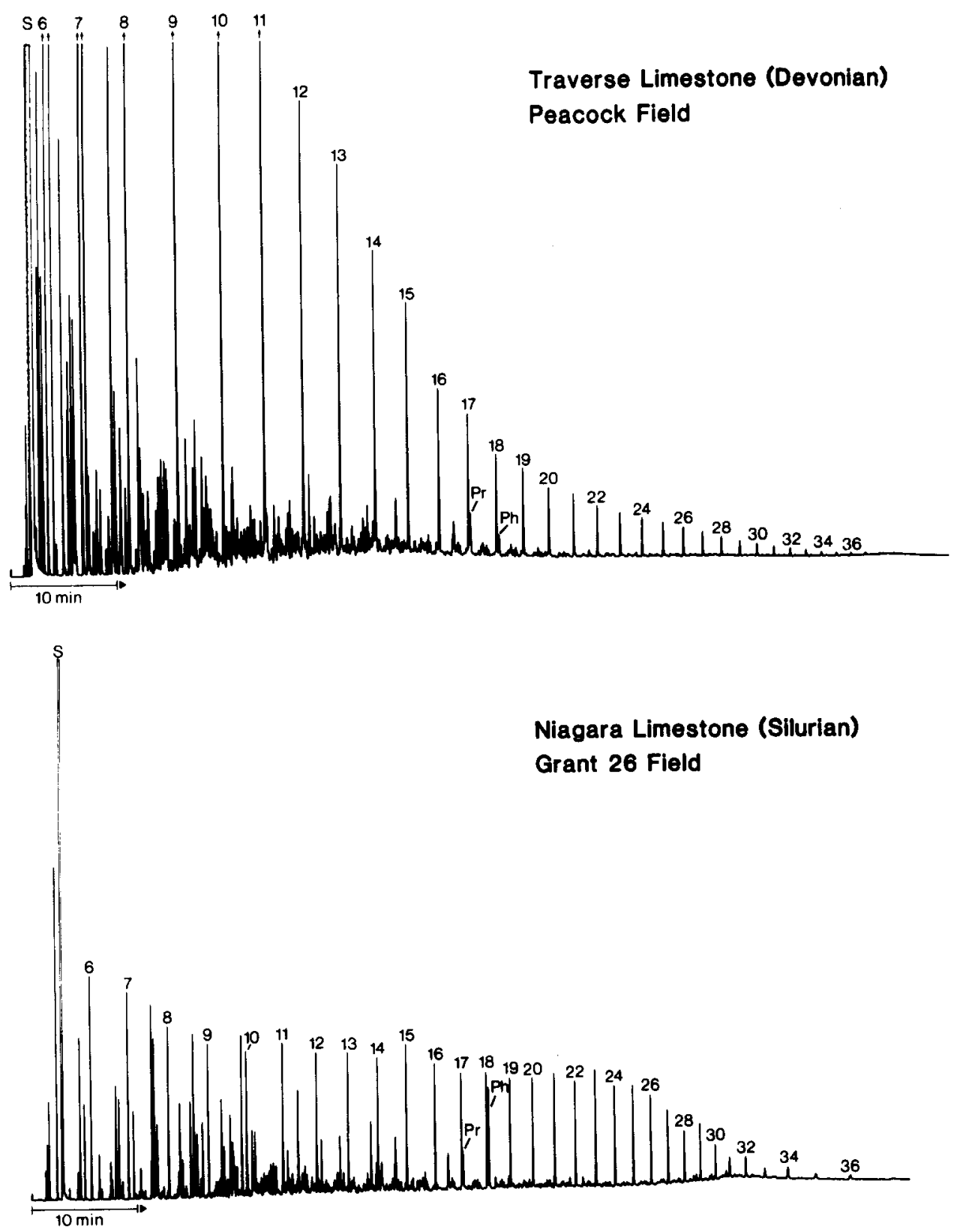

Fig. 5. Whole oil gas chromatograms of typical crude oils from Devonian Traverse Limestone and Silurian Niagara Limestone reservoirs in the Michigan Basin. Numbers indicate $n$-alkanes; Pr=pristane, $\mathrm{Ph}=$ phytane.

a weak even-carbon-number predominance of the $n$-alkanes below $\mathrm{C}_{20}$ (e.g. No. 13).

\section{Cyclohexylalkanes}

The Ordovician and Devonian Dundee oils contain abundant 1-cyclohexylalkanes with a pattern similar to that of the $n$-alkanes, i.e. there is a distinct odd-carbon-number predominance up to a chain length of $\mathrm{C}_{17}$ (1-cyclohexyl heptadecane) and a sudden decrease in concentration for the higher homologues (Fig. 6). The other two oil types show different cyclohexylalkane distributions (Fig. 6). The concentration of these compounds relative to the $n$-alkanes is higher in the Ordovician and Devonian Dundee oils by a factor of about ten compared to the Silurian oils and by a factor of about two relative to the Devonian Traverse oils.

$\omega$-Cyclohexyl fatty acids have been reported as membrane constituents of acidothermophilic bacteria (Oshima et al., 1978; Kannenberg et al., 1984). They can constitute up to $80 \%$ of the membrane fatty acids if the organisms are cultivated at the maximum growth temperature.

The microbial cyclohexyl fatty acids in recent organisms, however, have a chain length of $C_{11}$ or $C_{13}$ corresponding to $\mathrm{C}_{10}$ or $\mathrm{C}_{12}$ in the related hydrocarbons after decarboxylation. Thus, compounds of this origin are unlikely to be responsible for the 


\section{Alkyl Cyclohexane Distributions}

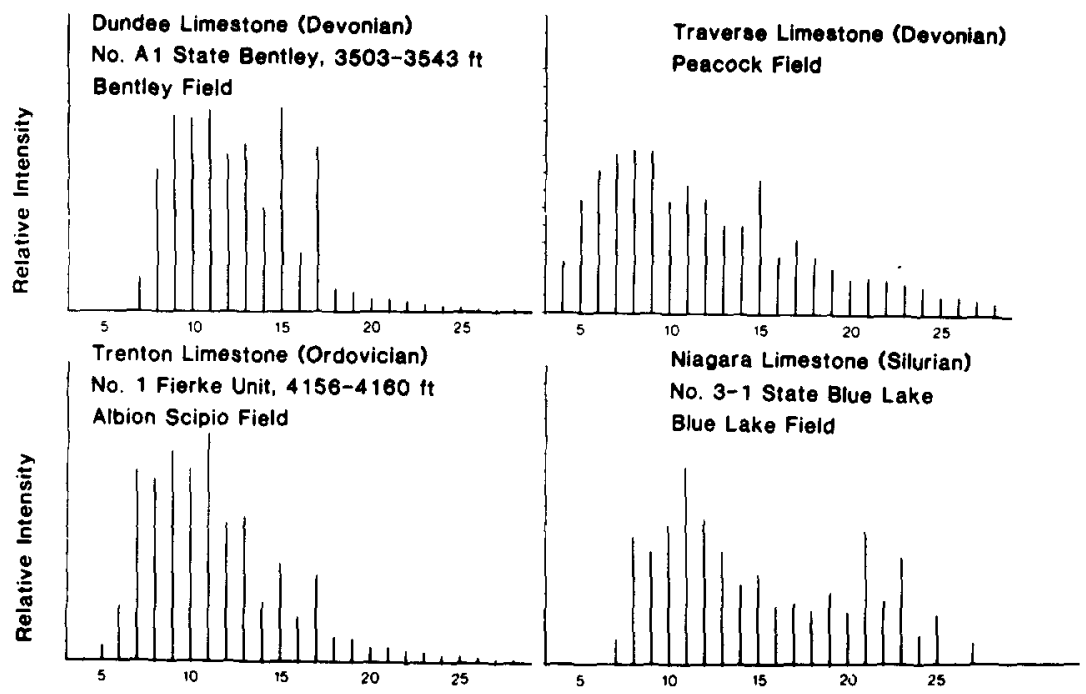

Fig. 6. 1-Cyclohexylalkane distributions of four representative crude oils from the Michigan Basin. Numbers on the $\mathrm{x}$-axis indicate chain length of $n$-alkyl moieties.

cyclohexylalkane pattern of the crude oils shown in Fig. 6. Higher molecular weight cyclohexyl fatty acids with 16 or 18 carbon atoms in the chain have been found in flue-cured tobacco (Mold et al., 1966)), although the authors could not exclude the possibility of these compounds being artifacts formed by heat from some precursors in the leaves. Decarboxylation of these compounds would explain the cyclohexylalkane patterns of the Trenton and Dundee oils in Fig. 6 regardless of the possibility of the fatty acid precursors being biogenic or diagenetic products. Artificial maturation experiments performed on stearic and oleic acids by Rubinstein and Strausz (1979) showed that cyclohexylalkanes are indeed formed but that the carboxyl carbon is retained. The cyclohexylalkane distribution of the Silurian oil with a second maximum at an alkyl chain length of $C_{21}$ indicates that there may be a specific group of precursor compounds in this case differentiating between higher plants (Silurian oils) and planktonic/ microbial origin (Ordovician/Devonian Dundee oils). No cyclohexyl fatty acids were detected in the total fatty acid fraction of the Dundee oil investigated.

\section{Steroid and hopanoid biological markers}

Sterane $(m / z 217)$ and terpane $(m / z 191)$ distributions of four representative oil samples are shown in Figs 7 and 8. Table 3 summarizes the biological marker compound ratios for all oils studied. The low biological marker concentrations, particularly those of the hopanes in the Silurian oils and of the aromatic steroids in general, prohibited the calculation of a complete set of compound ratios and occasionally affected the accuracy of these calculations due to low signal-to-noise ratios.

The $\mathrm{C}_{29}$ steranes are the dominant homologues in all oils from the Michigan Basin, and thus the sterane carbon number distributions do not clearly separate the oils into genetic families, although there is the tendency for the Ordovician oils to have a slightly lower $\mathrm{C}_{29}$ sterane concentration than the Devonian Dundee oils and for the Silurian oils to be slightly enriched in $C_{28}$ steranes relative to all other oils (Fig. 9). It should be emphasized that the $\mathrm{C}_{29}$ sterane predominance in the Michigan Basin oils is not related to a strong terrigenous organic matter influence (cf. Huang and Meinschein, 1979). The Ordovician and the Devonian Dundee oils due to their characteristic $n$-alkane pattern are likely to be from a source rock of Ordovician age, when land plants had not developed, and the Silurian oils despite their notable terrigenous component in the $n$-alkane pattern do not have a high triterpane/ sterane ratio which is common in oils of terrigenous organic matter origin.

In the Silurian oils diasteranes are absent or present in very low concentrations. This corroborates the conclusion based on the high phytane/pristane ratios, that these oils are derived from a source rock with a carbonate matrix. All Ordovician and Devonian oils contain abundant $\mathrm{C}_{27}$ and $\mathrm{C}_{29}$ diasteranes

Fig. 7. Sterane distributions of four representative crude oils from the Michigan Basin (mass fragmentograms of ion $m / z 217$ ). X-axis is scan number (or retention time). $d=C_{27}$ and $C_{29}$ diasteranes (cf Ensminger et al., 1978). $1=24$-ethyl-14 $(\mathrm{H}) 17 \alpha(\mathrm{H})$-cholestane $(20 \mathrm{~S}), 2=24$-ethyl-14 $\beta(\mathrm{H}), 17 \beta(\mathrm{H})$-chol-

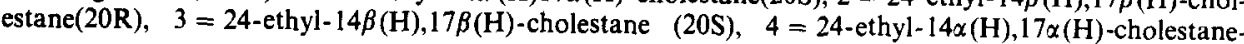




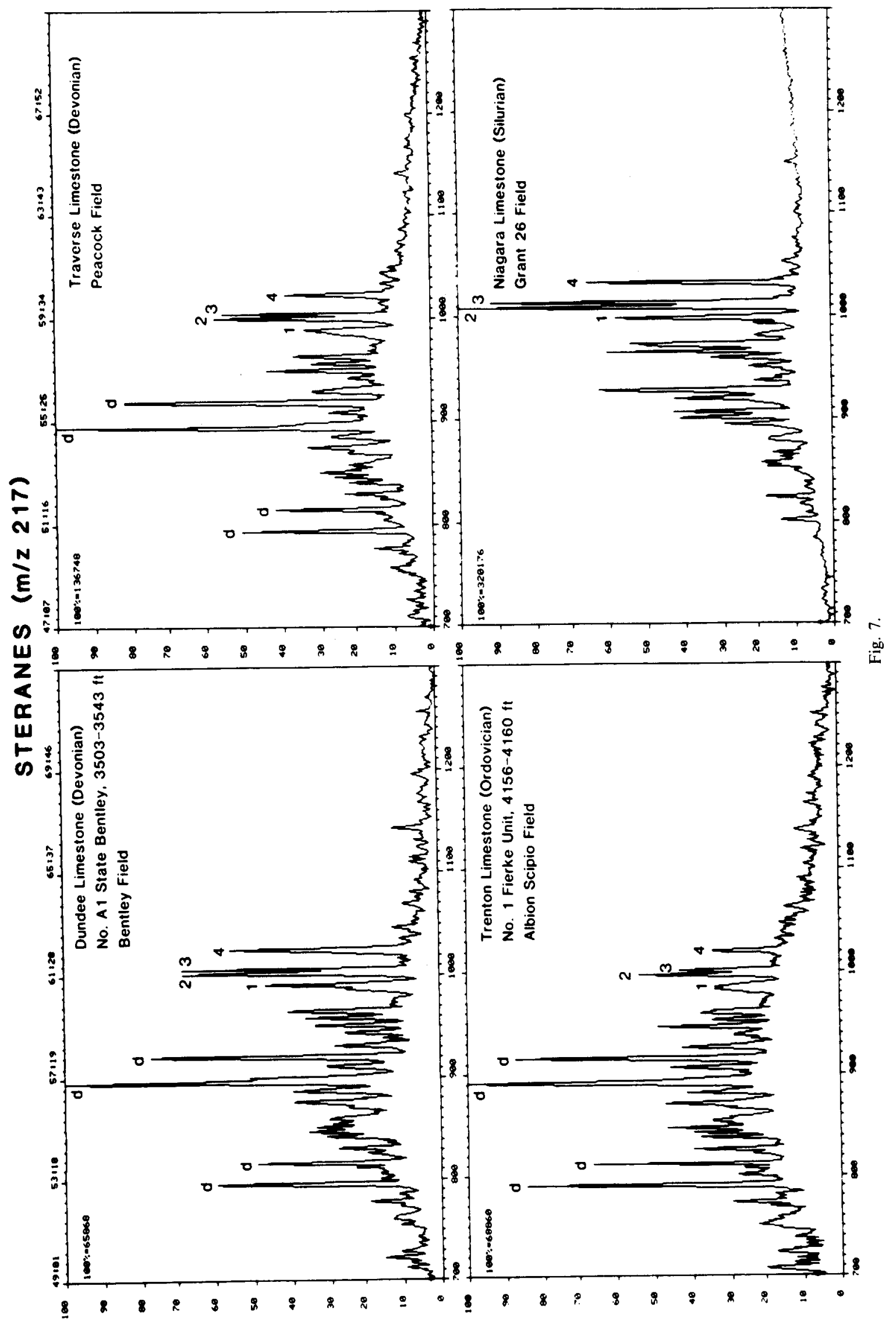




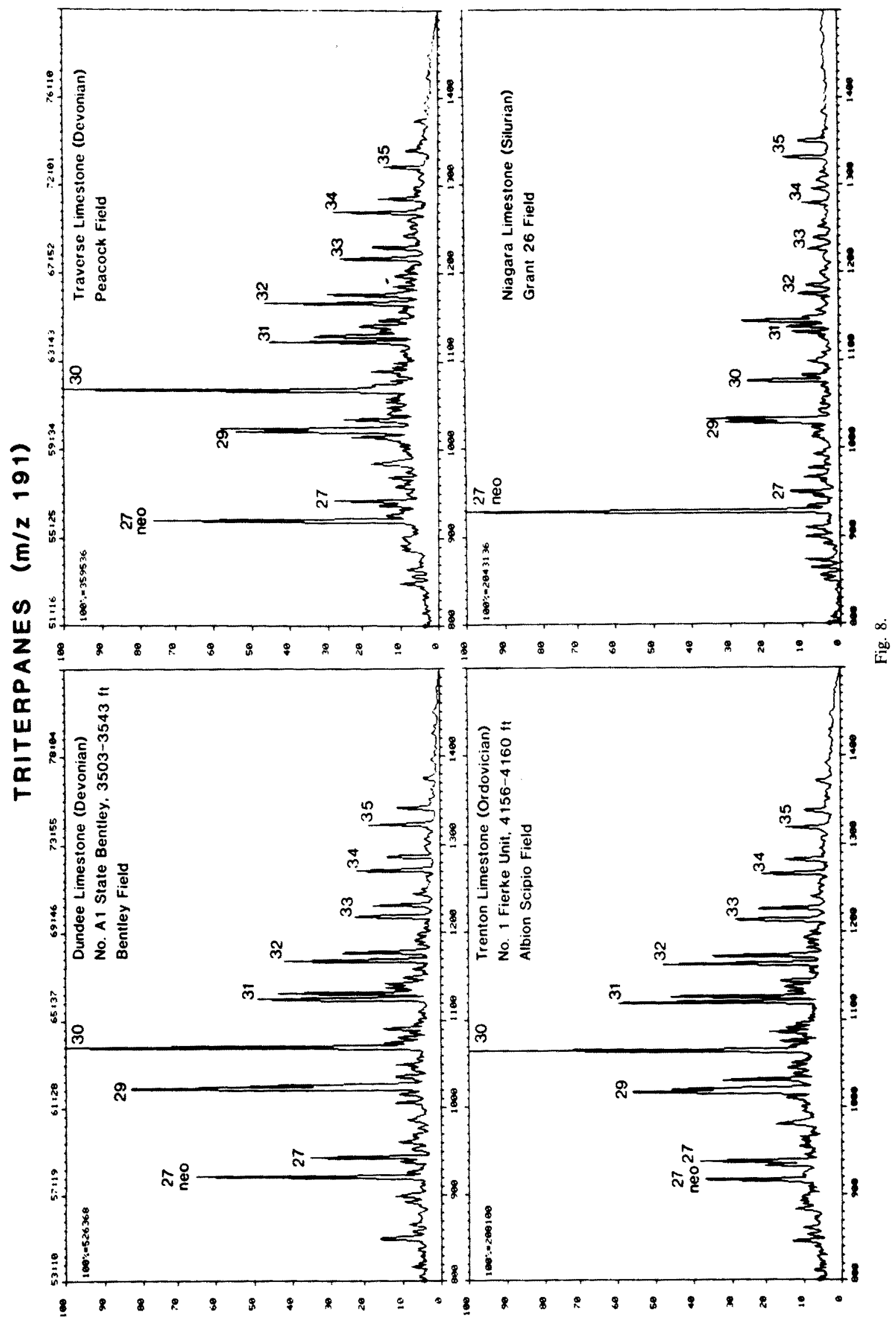


Table 3: Biolugical marker compound ratios for crude oils from the Michigan Basin.

\begin{tabular}{|c|c|c|c|c|c|c|c|c|c|c|c|c|c|}
\hline \multirow{3}{*}{ No. } & \multirow{3}{*}{ Reservoir Fm. } & \multirow{3}{*}{ Field } & \multirow{3}{*}{ Depth (ft) } & \multicolumn{6}{|c|}{ Steroids } & \multicolumn{3}{|c|}{ Hopanes } & \multirow{3}{*}{$R_{c}(\%)^{8 r}$} \\
\hline & & & & \multicolumn{3}{|c|}{ Carbon No. $(\%)^{\prime \prime}$} & \multirow{2}{*}{$\frac{20 S^{2 !}}{20 S+20 R}$} & \multirow{2}{*}{$\frac{\beta \beta^{31}}{\alpha \alpha+\beta \beta}$} & \multirow{2}{*}{$\frac{\operatorname{trr}^{4}}{\operatorname{tri}+\operatorname{mono}}$} & \multirow{2}{*}{$\frac{22 S^{s+1}}{22 \bar{S}+22 \bar{R}}$} & \multirow{2}{*}{$\frac{\text { neo- } C_{27}{ }^{61}}{n e 0-C_{27}+C_{27}}$} & \multirow{2}{*}{$\frac{\text { hop }^{\prime}}{\text { hop + mor }}$} & \\
\hline & & & & 27 & 28 & 29 & & & & & & & \\
\hline 2 & Stray Ss. & Clare & $1301-1306$ & 25 & 11 & 64 & 0.37 & 0.51 & 0.33 & 0.65 & 0.46 & 0.89 & 0.68 \\
\hline 5 & Berea Ss. & Saginaw & 1826 & 32 & 19 & 49 & 0.40 & 0.58 & 0.38 & 0.61 & 0.70 & 0.94 & 0.68 \\
\hline 35 & Traverse Ls. & Peacock & & 25 & 15 & 60 & 0.46 & 0.78 & n.d. ${ }^{\prime \prime}$ & 0.63 & 0.80 & 0.89 & 0.72 \\
\hline 34 & Traverse Ls. & Stanton & $2895-2907$ & 24 & 19 & 57 & 0.49 & 0.74 & $0.64(?)^{10}$ & 0.52 & 0.64 & 0.94 & 0.74 \\
\hline 9 & Dundee Ls. & Bentley & $3505-3543$ & 22 & 16 & 62 & 0.46 & 0.78 & n.d. & & 0.68 & 0.89 & 0.58 \\
\hline 12 & Dundee Ls. & N. Adams & $2876-2884$ & 29 & 14 & 57 & 0.52 & 0.72 & n.d. & 0.55 & 0.44 & 0.92 & 0.56 \\
\hline 104 & Dundee Ls. & Crystal & $3178-3184$ & 26 & 15 & 59 & 0.54 & 0.75 & n.d. & 0.62 & 0.78 & 0.96 & 0.66 \\
\hline 105 & Dundee Ls.(?) & Oil Springs & & 25 & 19 & 56 & 0.41 & 0.64 & n.d. & 0.58 & 0.54 & 0.94 & 0.52 \\
\hline 8 & Dundee Ls. & Bentley & $3523-3550$ & 23 & 15 & 62 & 0.50 & 0.70 & n.d. & 0.60 & 0.80 & 0.94 & 0.52 \\
\hline 25 & Dundee Ls. & Rosebush & $3693-3709$ & n.d. & n.d. & n.d. & n.d. & n.d. & n.d. & 0.59 & 0.78 & 100 & 0.58 \\
\hline 27 & Dundee Ls. & N. Buckeye & $3558-3663$ & 22 & 17 & 61 & 0.57 & 0.71 & n.d. & 0.62 & 0.56 & 0.91 & 0.59 \\
\hline 7 & Detroit River & Hamilton & $5205-5312$ & 21 & 14 & 65 & 0.49 & 0.72 & n.d. & n.d. & n.d. & n.d. & 0.69 \\
\hline 6 & Ls. Detroit Aiver Sour & Skeels & $\begin{array}{l}4847-4855 \\
5056-5085\end{array}$ & nd. & nd. & n.d. & n.d. & n.d. & n.d. & n.d. & n.d. & n.d. & 0.66 \\
\hline 11 & Detroit River Sour & S Buckeye & $4481-4512$ & n.d. & n.d. & n.d. & n.d. & n.d. & n.d. & n.d. & n.d & n.d. & $0.84 ?\}$ \\
\hline 13 & Niagaran Salina Ls. & Onondaga 10 & $3850-3870$ & 23 & 23 & 54 & 0.42 & 0.73 & n.d. & n.d. & 0.85 & n.d. & 0.89 \\
\hline 1 & Niagaran Salina Ls. & Vevay 16 & $\begin{array}{l}4165-4179 \\
4202-4204\end{array}$ & 20 & 22 & 58 & 0.50 & 0.76 & n.d. & 0.62 & 0.88 & 0.95 & 0.93 \\
\hline 17 & Niagara Ls. & Pennfield & $\begin{array}{l}2695-2699 \\
2704-2722\end{array}$ & 25 & 20 & 55 & 0.36 & 0.70 & n.d. & 0.53 & 0.43 & 0.90 & 0.96 \\
\hline 33 & Niagara Ls. & Carleton 4 & $4766-4882$ & 14 & 25 & 61 & 0.42 & 0.73 & n.d. & n.d. & n.d. & n.d. & 0.95 \\
\hline 26 & Niagara Ls. & Chester 15 & $5930-6278$ & 23 & 21 & 56 & 0.59 & 0.75 & n.d. & n.d. & n.d. & n.d. & 0.94 \\
\hline 21 & Niagara Ls. & Blue Lake & & 27 & 24 & 49 & 0.46 & 0.75 & n.d. & n.d. & 0.89 & n.d. & 0.92 \\
\hline 15 & Niagara Ls & Grant 26 & & 19 & 26 & 55 & 0.45 & 0.76 & $0.79(?)$ & n.d. & 0.89 & $0.79(?)$ & 0.97 \\
\hline 107 & Niagara Ls. & Rapid River 27 & & 16 & 32 & 52 & 0.44 & 0.77 & n.d. & n.d. & n.d. & n.d. & 0.93 \\
\hline 14 & Trenton Ls. & Albion-Scipio & $4156-4160$ & 28 & 19 & 53 & 0.46 & 0.78 & n.d. & 0.59 & 0.44 & 0.89 & 0.59 \\
\hline 24 & Trenton LS. & Deerfield & $2113-2160$ & 27 & 21 & 52 & 0.47 & 0.75 & n.d. & $0.52(?)$ & 0.67 & 1.00 & 0.70 \\
\hline 30 & Trenton Ls. & Blissfield & $2686-2727$ & n.d. & n.d. & n.d. & n.d. & n.d. & n.d. & n.d. & n.d. & n.d. & 0.84 \\
\hline 109 & Trenton Ls. & Fortuna & 4535 & 39 & 19 & 42 & 0.50 & 0.72 & n.d. & 0.64 & 0.55 & 0.94 & 0.58 \\
\hline \multirow[t]{2}{*}{19} & Trenton-Black River Ls. & Northville & $4262-4290$ & 25 & 22 & 53 & 0.41 & 0.70 & n.d. & 0.60 & 0.74 & 1.00 & 0.74 \\
\hline & & & $4320-4374$ & & & & & 0.72 & & & & & \\
\hline 18 & Trenton-Black River Ls. & Hannover & $4368-4375$ & 30 & 19 & 51 & 0.52 & & n.d. & 0.65 & 0.76 & 1.00 & 0.71 \\
\hline 4 & Trenton-Black River Ls. & Albion-Scipio & $3919-3924$ & 22 & 20 & 58 & n.d. & n.d. & n.d. & 0,60 & 0.62 & 1.00 & 0.62 \\
\hline 32 & Black River Ls. & Albion-Scipio & $4770-4812$ & 24 & 24 & 52 & n.d. & n.d. & n.d. & 0.66 & 0.43 & 1.00 & 0.63 \\
\hline
\end{tabular}

1) $14 \beta(H), 17 \beta(H)-$ steranes $(m / 2218)$

2) $\mathrm{C}_{z 9} 14 \alpha(H), 17 \alpha(H)$-steranes $(\mathrm{m} / \mathrm{z} 217)$

3) $C_{2} 14 \beta(H), 17 \beta(H)$ - and $14 \alpha(H), 17 \alpha(H)$-steranes $(m / 2217$; intensity of $14 \beta(H), 17 \beta(H)$-steranes multiplied by a factor of two)

4) $\mathrm{C}_{2 \mathrm{a}}$ triaromatic(2OP)- and $\mathrm{C}_{28}$ monoaromatic(2OP) steroids $(\mathrm{m} / \mathrm{z} 231$ and 253): for calculation procedure see Mackenzie et al. (1981)

5) $C_{32} 17 \propto(H)$-hopanes $(m / 2191)$
6) $18 \alpha(H)$-trisnorneohopane $(A)$ and $17 \alpha(H)$-trisnomopane $(m / z$ 191)

7) $17 \alpha(H)$-hopane and moretane $(m / 2191)$

8) calculated vitrinite reflectance from methylphenanthrene index (MPI) based on molecular ions of phenanthrene $(\mathrm{m} / \mathrm{z}, 178)$ and methylphenanthrenes $(\mathrm{m} / \mathrm{z} 192)$; similar to the method of Radke et $a$ ). (1982).

9) n.d. = not determined

10) ? questionable due to low biomarker concentrations
(Fig. 7) indicating clay catalysis in their source rocks (Sieskind et al., 1979).

The triterpane patterns of the Ordovician and Devonian oils, including the Traverse oils, resemble those of a typical mature oil (Fig. 8). Some variation occurs in the ratio of $18 \alpha(\mathrm{H})$-trisnorneohopane (neo$\mathrm{C}_{27}$ in Fig. 8) and $17 \alpha(\mathrm{H})$-trisnorhopane $\left(\mathrm{C}_{27}\right)$ but without any systematic trend (Table 3 ). The triterpane distributions of the Silurian oils are dominated by an extremely abundant $18 \alpha(\mathrm{H})$-trisnorneohopane peak (Fig. 8). Such a distribution is commonly observed only in very mature sediments and crude oils. In the Michigan Basin, this extreme $18 \alpha(\mathrm{H})-$ trisnorneohopane abundance is more pronounced in the oils from the northern Niagaran reef reservoirs (Nos. 33, 26, 21, 15, 107; Table 3) than in those from the southern belt of Silurian reservoirs (Nos. 13, 1, 17; Table 3). It is not clear, however, whether this is due to differences in maturity or in source facies.

The aromatic steroid hydrocarbon concentrations were extremely low in most of the oils. The extent of steroid aromatization could confidently only be determined in the Stray and Berea oils where it is low (around 0.35; Table 3). In the Ordovician and Devonian Dundee/Detroit River oils the lack of aromatic steroid hydrocarbon data is related to the 


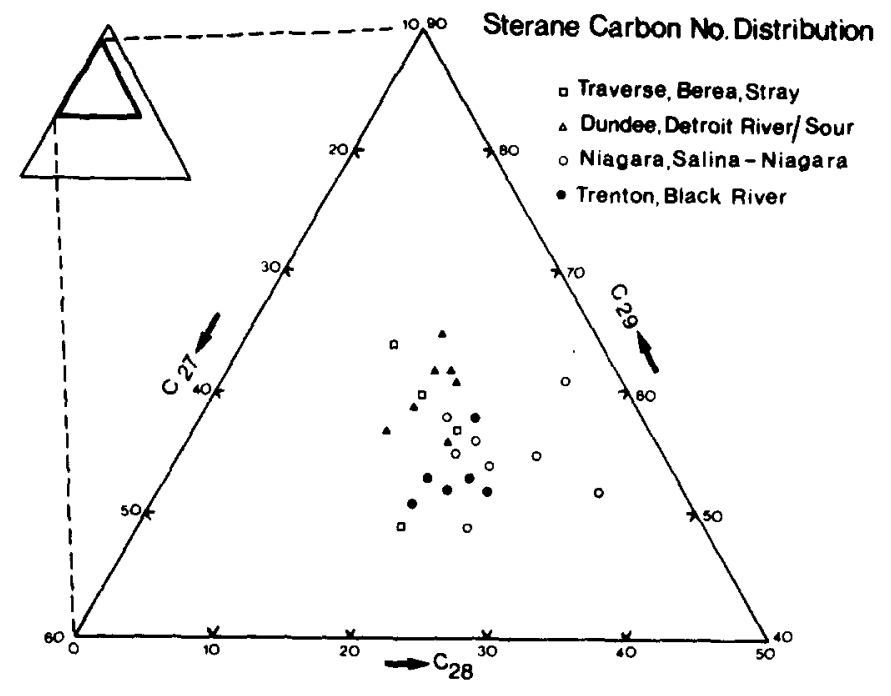

Fig. 9. Triangular diagram representation of $\mathrm{C}_{27}-\mathrm{C}_{29}$ sterane carbon number distribution of crude oils from the Michigan Basin (calculated from $m / z 218$ mass fragmentograms).

generally low concentration of the steroid hydrocarbons in these samples. It is less evident why the extent of steroid aromatization could not be determined in the Silurian oils.

\section{Methylphenanthrenes}

Compound ratios from the alkyl phenanthrene distributions in geological samples have been introduced as chemical maturity parameters by Radke $e t$ al. $(1982,1983,1984)$. The intensity distributions of phenanthrene, methylphenanthrenes and dimethylphenanthrenes for four crude oils from the Michigan Basin are shown in Fig. 10 as summed ion traces of the respective mass spectrometric molecular ions. Obviously, two types of patterns occur, and the examples shown in Fig. 10 are representative of the corresponding other samples from reservoirs of the same or similar age as grouped in Table 3. The Silurian oils have relatively low phenanthrene concentrations, and 2-methyl-phenanthrene is the most abundant methylphenanthrene isomer. In contrast to this, a predominance of 9-methylphenanthrene is common to all other oils. In addition, the relative concentration of dimethylphenanthrenes is lower in the Ordovician and Devonian oils than in the Silurian oils (Fig. 10).

Methylphenanthrene index values (Radke et al., 1983) were calculated from the peak areas of phenanthrene and the methylphenanthrenes. A correction factor of 0.7 had to be applied to the phenanthrene peak area in order to compensate for differences between mass spectrometer and flame ionization detector sensitivities (H.-G. Bittner, unpublished results). The Methylphenanthrene Index values were converted to calculated vitrinite reflectance equivalents $\left(R_{c}\right.$; Table 3$)$. The Silurian oils clearly show the highest $R_{\mathrm{c}}$ values ranging from 0.89 to $0.97 \%$ and with an average value of $0.94 \%$. There is only little variation among the Traverse/Berea/Stray oils, and the average $R_{\mathrm{c}}$ value is $0.71 \%$. According to the methylphenanthrenes, the Ordovician and Devonian Dundee/Detroit River oils have the lowest thermal maturity with average $R_{\mathrm{c}}$ values of $0.68 \%$ and $0.62 \%$, respectively. The values vary between $0.59 \%$ and $0.74 \%$ in the Ordovician oils and between $0.52 \%$ and $0.69 \%$ in the Devonian Dundee/Detroit River oils, but a single higher $R_{\mathrm{c}}$ value of $0.84 \%$ was measured in each group (Table 3).

\section{Oil families and source rock delimitation in the Michi-} gan Basin

From the previous discussion it is evident that three distinct oil types exist in the Michigan Basin. One of them is the Ordovician type found in the Ordovician Trenton and Black River Limestone reservoirs. These oils have the characteristic $n$-alkane pattern common to a series of early Palaeozoic crude oils found world-wide (e.g. Martin et al., 1963; McKirdy et al., 1983; Zumberge, 1983; Fowler and Douglas, 1984; Reed et al., 1986). All other geochemical parameters in our study also show that the Ordovician oils form a common group and that an influence from younger strata is unlikely. An influence from older strata also can be ruled out because the dominant lithology in the Cambrian is sandstone with some dolomite in the Trempealeau Formation (McMullan and Slaughter, 1964) which acts as a reservoir. Nearly all of the Early and Middle Ordovician consists of limestone or dolomite including the Trenton and Black River Limestones (McMullan and Slaughter, 1964). Because the Ordovician oils in the Michigan Basin contain abundant diasteranes and exhibit a strong odd-over-even carbon number predominance below $n-\mathrm{C}_{20}$ in their $n$-alkane distributions, the Utica Shale at the base of the Late Ordovician appears to be a reasonable choice of an 
Ordovician source when searching for a clastic rock matrix. Other less important shale layers in the Late Ordovician may, however, also have made a contribution. It is also quite possible that clay-bearing carbonates functioned as sources of these Ordovician oils.

The same source responsible for the Ordovician oils has also supplied the bulk of the hydrocarbons found in the Devonian Dundee and Detroit River reservoirs. Many of the geochemical parameters provide substantial evidence for a close relationship to the Ordovician oils, although numerous details show that there is not a perfect match. Some of the differences seem to be related to differences in thermal maturity, but some mixing also may have occurred. This is more significant for the Detroit River oils which certainly contain a contribution from Silurian type oils, but may also apply to the Dundee oils, which would, however, have received hydrocarbons from a clay-bearing source rock either from a Devonian rock or from the Ordovician source but at a different stage of generation. We consider the remote possibility rather unlikely that similar biota and depositional environments existed about $100 \mathrm{Ma}$ apart in the Ordovician and Devonian particularly because of the unique composition of the early Palaeozoic oils.

Having established the genetic relationship between the Ordovician and the Devonian Dundee/Detroit River oils, we think that there is a strong argument that migration must have occurred through what today appears to be an impermeable barrier of Silurian evaporite deposits. In addition, large volumes of oil migrated without mixing with the completely different type of Silurian oils. A final conclusive confirmation of the migration path needs a detailed reconstruction of the geological history of the Michigan Basin.

The second type of oils comes from the Niagara Dolomite and the Niagaran section of the Salina Dolomite (Engadine Dolomite) which are overlain or intercalated with a series of evaporites of Middle Silurian age (McMullan and Slaughter, 1969). The oils may have been generated more or less in situ because the high phytane/pristane ratios and the near-absence of diasteranes indicate a carbonate or evaporite source rock matrix. The presence of small amounts of diasteranes in some of the Silurian oils

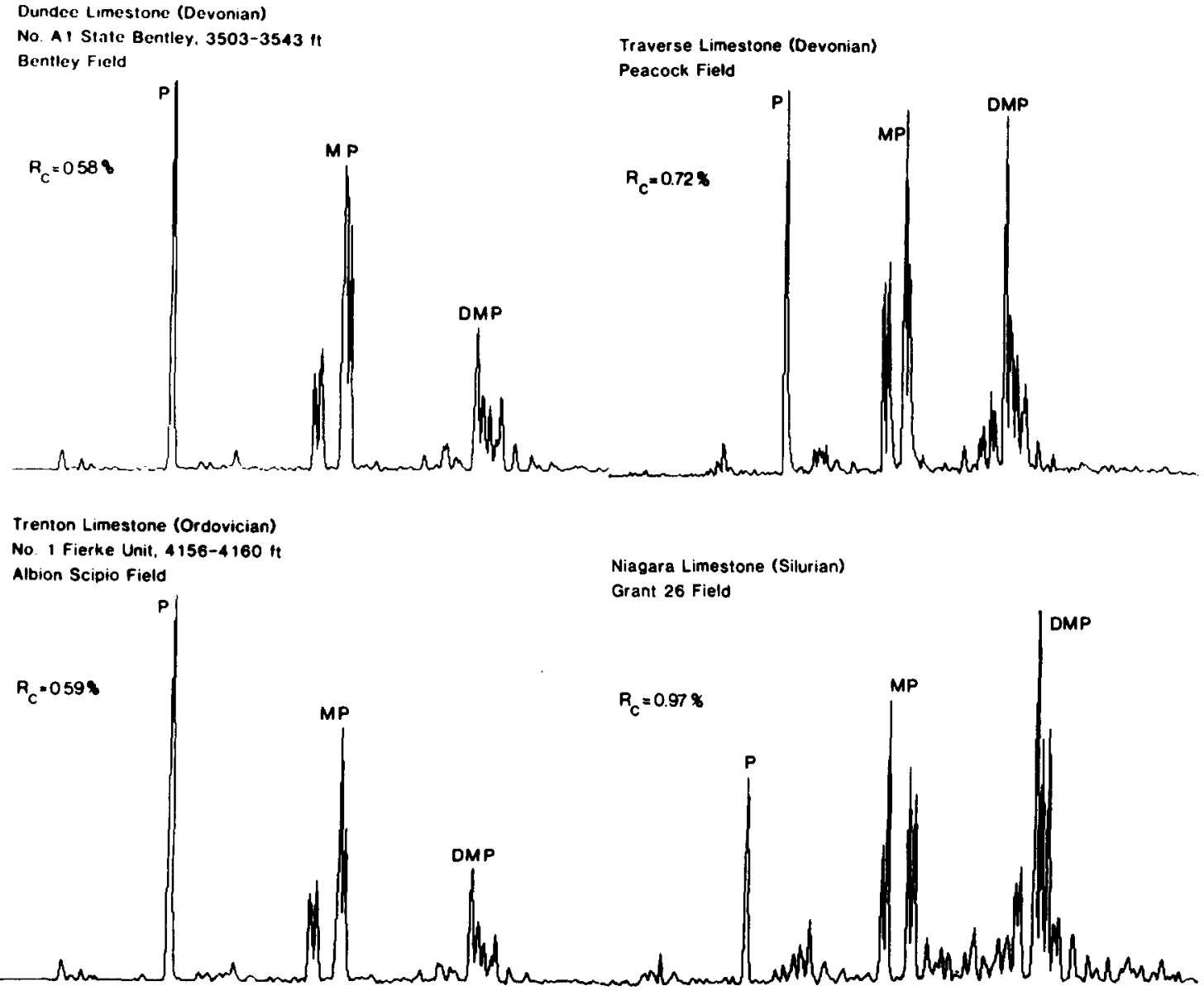

Fig. 10. Phenanthrene (P), methyl- (MP) and dimethylphenanthrene (DMP) distribution of four representative crude oils from the Michigan Basin. $R_{\mathrm{c}}=$ calculated vitrinite reflectance equivalents (cf. text and Radke et al., 1983). 
may be due to some mixing with Ordovician oils but no other evidence is found for this, and thus it is rather unlikely due to the very low sterane concentrations in the Ordovician oils. The diasteranes may also arise from a contribution from the Late Silurian Pte.-aux-Chenes Shale, or they may reflect the presence of clays in the carbonate source rocks.

The third Michigan Basin oil type, as noted before by Pruitt (1983), and Illich and Grizzle (1983), comprises those from the Traverse Limestone (Devonian), the Berea Sandstone (Devonian) and the Stray Sandstone (Early Mississippian). The Berea Sandstone is embedded in a sequence of shales including the Antrim, Ellsworth and Coldwater Shales (McMullan and Slaughter, 1964). The Stray Sandstone as part of the Marshall Formation (all sandstone) overlies this shale sequence whereas the Traverse Formation is below it. Given sufficient maturity, the shale sequence would be a likely candidate for the source of the Traverse type oils, because the composition of the oils suggests a clastic source rock. If migration from deeper strata is considered, only the Pte.-aux-Chênes Shale (Late Silurian) would be an alternative.

Although the Traverse type oils have some compositional features in common with the other two oil types from the Michigan Basin, mixing of oils from the Ordovician and the Silurian would not be able to explain, e.g. the isoprenoid hydrocarbon together with the $n$-alkane composition even if maturity differences are considered. Although the compositional variation of the Traverse type oils is larger than that of the other oil types (see e.g. Figs 3 and 7), the existence of a third active source rock in the Michigan Basin has to be assumed as stated earlier by Pruitt (1983) and Illich and Grizzle (1983).

\section{Crude oil maturity and implications for the thermal and migration history}

The reconstruction of oil generation and migration in the Michigan Basin despite its relatively simple geological setting is complicated by its considerable age. Under the assumption that hydrocarbon generation already started a significant amount of time before present, there was ample time and opportunity for long-range migration (Momper, 1978) with associated fractionation, for physical separation and emplacement processes in the reservoirs (Gill, 1979), and for mixing of oils from different sources and from different stages of generation of a given source rock. All these processes to a certain extent may affect maturity assessment using geochemical maturity parameters. Depending on the processes involved and the nature of the compounds considered, low molecular weight compounds, polar compounds or compounds with a low initial concentration usually will be affected the most but in different ways. Therefore, to find a congruent picture for all members of a certain genetic oil family and for all maturity parameters cannot be expected.
Several parameters indicate that both the Ordovician and Devonian Dundee oils are not fully mature. In this respect the $n$-alkane distributions (odd-over-even carbon number predominance; Fig. 4) are consistent with the calculated vitrinite reflectance equivalents based on the distribution of the alkyl phenanthrenes (Fig. 9; Table 3). The conflicting high heptane values (Table 2) may be attributed to the specific character of the source organic matter containing mainly straight-chain precursors (e.g. normal fatty acids) in its lipid portion, whereas the relatively high total hydrocarbon contents may be the result of fractionation (loss of polar material) during long-distance migration.

Differences between the Ordovician and Devonian Dundee oils are also reflected in the geochemical maturity parameters which almost consistently show the Ordovician oils to be the slightly more mature ones. Among these parameters are the $R_{\mathrm{c}}$ values (Table 3), the total hydrocarbon and asphaltene contents (Table 1) and the stable carbon isotope ratios of the saturated and aromatic hydrocarbon fractions (Fig. 3).

The extent of sterane isomerization is variable among the Ordovician type oils, but only a few samples have reached the equilibrium value (Table 3 ). In order to get an impression of how the biological marker maturity parameters would develop under the geological conditions of the Michigan Basin, a rough calculation was made using the kinetic parameters and equations of Mackenzie and McKenzie (1983) for isomerization of steranes at C-20 and aromatization of monoaromatic into triaromatic steroid hydrocarbons, the concept of the effective heating time (time spent within $15^{\circ} \mathrm{C}$ of the maximum temperature), the burial history of the Middle Ordovician (Fig. 11), data from present day conditions in Silurian and Devonian sediments near the center of the basin (Nunn and Sleep, 1984) assuming times of non-deposition or insignificant erosion at the unconformities, and the present temperature distribution in the basin. The result summarized in Table 4 indicates that both the isomerization and aromatization reactions would be complete in base Middle Ordovician sediments. Isomerization would be complete at the base of the Silurian with the aromatization having reached a value of 0.84 , whereas base Devonian sediments would be immature particularly with respect to steroid aromatization due to the low maximum temperature of $58^{\circ} \mathrm{C}$.

For the Ordovician type oils this would mean that their bulk proportion is not from the deepest part of the basin. The deepest part of the Ordovician source rock may have generated hydrocarbons in the past but the majority of this may have been lost during the geological history by leakage of the reservoirs, possibly associated with erosional events. The steranes and hopanes found in the Ordovician type oils are considered indigenous and not a contribution from another source or collected during migration or in the reser- 


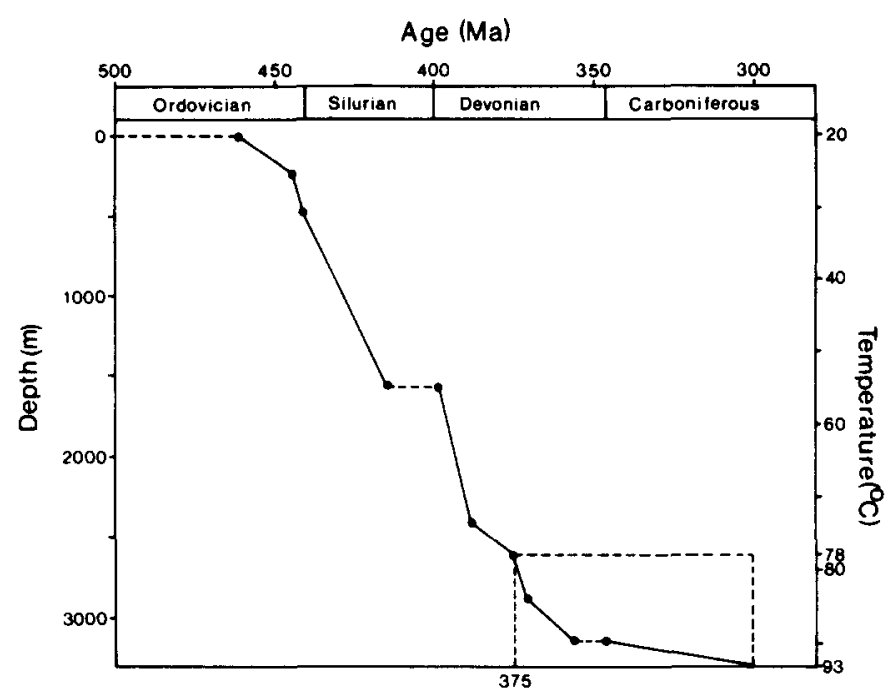

Fig. 11. Burial history curve for the base of the Middle Ordovician near the center of the Michigan Basin [after Sleep and Sloss (1978), and Nunn and Sleep (1984)]. Temperatures are from the present geothermal gradient of about $21^{\circ} \mathrm{C} / \mathrm{km}$ found in a deep borehole (Sleep and Sloss, 1978). Unconformities are considered as nondepositional events. Broken line rectangle indicates the time when the Middle Ordovician sediments reached the $15^{\circ} \mathrm{C}$ from maximum temperature interval $\left(t_{\mathrm{eff}} ; 375 \mathrm{Ma}\right.$ B.P.).

voir (Philp and Gilbert, 1982; Rullkötter et al., 1984) because their overall pattern is fairly consistent in the Trenton as well as in the Dundee oils. The failure to measure the extent of steroid aromatization is assumed to be a consequence of the low initial steroid concentration. The low polycyclic biological marker concentrations of all these oils is obvious from the whole oil gas chromatograms (Fig. 4), and the absolute concentration of aromatic steroids usually is at least an order of magnitude lower than that of the saturated steranes (Rullkötter et al., 1984).

The most mature oils based on total saturated hydrocarbon contents, asphaltene content, vitrinite reflectance equivalent $\left(R_{\mathrm{c}}\right)$ and $18 \alpha(\mathrm{H})$-trisnorneohopane to $17 \alpha(\mathrm{H})$-trisnorhopane ratio are those from the Silurian reservoirs. Again, the sterane isomerization, the odd carbon number preference of the $n$-alkanes and some of the light hydrocarbon parameters are not completely consistent with this. As has been pointed out before, the Silurian oils are considered more or less indigenous, but some mixing will have occurred of hydrocarbons from the center of the basin (with major influence on the bulk parameters including the $R_{\mathrm{c}}$ values) and from shallower marginal portions of the source rock (influencing, e.g. the sterane isomerization values; of. Mackenzie et al., 1986). In addition, because the oils are from a carbonate source and the richest in sulfur (Illich and Grizzle, 1983) the methylphenanthrene derived $\boldsymbol{R}_{\mathrm{c}}$ values may be somewhat high according to our experience with other oils from carbonate sources (Rullkötter et al., 1985).

The Traverse type oils have a maturity intermediate to those types described before based on the $R_{\mathrm{c}}$ values and the $n$-alkane distributions. The shallowest samples from the Berea and Stray Sandstone contain relatively immature biological marker distributions, but even if a contribution from imma-

Table 4: Calculation of biological marker data from kinetic parameters for sediments in the center of the Michigan Basin using data and equations of Mackenzie and McKenzie (1983).

\begin{tabular}{|c|c|c|}
\hline & Steroid aromatization & Sterane isomerization \\
\hline $\begin{array}{c}\text { - Base Middle Ordov } \\
\mathrm{T}=93^{\circ} \mathrm{C} \\
\mathrm{t}_{\mathrm{at}}=375 \mathrm{Ma}\end{array}$ & 1.00 & 0.54 \\
\hline $\begin{array}{l}\text { - Base Silurian } \\
T=82^{\circ} \mathrm{C} \\
\mathrm{t}_{\mathrm{m}}=358 \mathrm{Ma}\end{array}$ & 0.84 & 0.54 \\
\hline $\begin{aligned} \text { - Base Devonian } \\
T=58^{\circ} \mathrm{C} \\
t_{\text {oft }}=332 \mathrm{Ma}\end{aligned}$ & 0.01 & 0.35 \\
\hline
\end{tabular}


ture organic matter associated with the reservoir rocks is considered, the values exceeded those calculated in Table 4. If a Devonian source is indeed considered for these oils-and we favour this interpretation-there must have been deeper burial in the past followed by later uplift unless it is assumed that the maturation parameters used are not calibrated for work with Palaeozoic basins. With respect to deeper subsidence we agree with the conclusion of Cercone (1984), but we probably do not have to assume a much higher heatflow in the geological past. Deeper burial would also help to explain the relatively high maturity of the Silurian oils, and would support the idea that much of the earlier generated hydrocarbons in the Ordovician source in the center of the basin has been lost in the geological past.

\section{CONCLUSIONS}

The investigation of thirty crude oils from Palaeozoic reservoirs in the Michigan Basin by a variety of organic geochemical techniques with emphasis on carbon isotope and biological marker studies has led to the confirmation of three genetic oil types and the presence of oils of mixed origin. The following families were identified:

(1) Trenton Limestone/Black River Limestone oils (Ordovician), and Dundee Limestone/Detroit River Limestone oils (Devonian), both from a clay-bearing Ordovician source with the Detroit River oils having the most significant contribution from a second source (mainly Silurian);

(2) Niagaran Salina Limestone/Niagara Limestone oils (Silurian) which are from a Silurian carbonate source;

(3) Traverse Limestone/Berea and Stray Sandstone oils (Devonian) mainly of Devonian origin with some contribution of Ordovician oil.

All oils carry the imprint of low maturity based on some (molecular) parameters, whereas other parameters indicate higher maturity. An explanation of the oil compositions requires the assumption of mixing of more mature hydrocarbons with hydrocarbons from shallower source rock portions and fractionation by long-range migration. The Silurian oils are the most mature oils followed by the Devonian Traverse type and the Ordovician type oils. To explain this succession, loss of early generated Ordovician oils and later generation from relatively shallow (immature) sections of the source rock is assumed.

Calculations using kinetic parameters of steroid reactions indicate that oil generation in the Michigan basin requires deeper subsidence of the source rocks in the geological past, especially because we favour a Devonian source for the Traverse type oils.

Acknowledgements - We would like to thank Dr M. Radke and $\mathrm{H}$. Willsch (KFA Jülich) for medium pressure liquid chromatography separation of the crude oils and preparation of a fatty acid methyl ester fraction. Discussions with Dr M. Radke were helpful to interpret the methylphenanthrene distributions. We are grateful to Professor
D. H. Welte (KFA Jülich) for his support of this study. Technical assistance by U. Disko, Miss A. Fischer, J. Höltkemeier, Mrs B. Kammer, F. J. Keller, Miss A. Richter and H. G. Sittardt is acknowledged as well as typing of the manuscript by Mrs B. Schmitz.

\section{REFERENCES}

Alexander R., Cumbers M. and Kagi R. I. (1984) Geochemistry of some Canning Basin crude oils. In The Canning Basin, Western Australia (Edited by Purcell P. G.). Proceedings of Geol. Soc. Aust./Pet. Expl. Soc. Aust. Symposium, Perth, pp. 353-358.

Attaway D. H., Parker P. L. and Mears J. A. (1970) Normal alkanes of five coastal spermatophytes. Contrib. Mar. Sci. 15, 13-19.

Cercone K. R. (1984) Thermal history of Michigan Basin. Bull. Am. Assoc. Pet. Geol. 68, 130-136.

Cohee G. V. and Landes K. K. (1958) Oil in the Michigan Basin. In Habitat of Oil (Edited by Weeks L. G.), pp. 473-493. Am. Assoc. Petr. Geol., Tulsa.

Daly A. R. and Lilly D. H. (1985) Thermal subsidence and generation of hydrocarbons in Michigan Basin: Discussion. Bull. Am. Assoc. Pet. Geol. 69, 1181-1184.

Dorr J. A. Jr and Eschmann D. F. (1970) Geology of Michigan, $476 \mathrm{pp}$. University of Michigan Press, Ann Arbor.

Dunham K. W., Meyers P. A. and Rullkötter J. (1986) Biomarker comparison of Michigan Basin oils. In Chemical Biomarkers (Edited by Yen T. F. and Moldowan J. M.). Am. Chem. Soc., Washington, in press.

Eglinton G. and Hamilton R. J. (1963) The distribution of alkanes. In Chemical Plant Taxonomy (Edited by Swain T.), pp. 187-217. Academic Press, New York.

Ensminger A., Joly G. and Albrecht P. (1978) Rearranged steranes in sediments and crude oils. Tetrahedron Lett., $1575-1578$.

Fowler M. G. and Douglas A. G. (1984) Distribution and structure of hydrocarbons in four organic-rich Ordovician rocks. In Advances in Organic Geochemistry 1983 (Edited by Schenck P. A., de Leeuw J. W. and Lijmbach G. W. M.). Org. Geochem. 6, 105-114. Pergamon Press, Oxford.

Gill D. (1979) Differential entrapment of oil and gas in Niagaran pinnacle-reef belt of northern Michigan. Bull. Am. Assoc. Pet. Geol. 63, 608-620.

Huang W.-Y. and Meinschein W. G. (1979) Sterols as ecological indicators. Geochim. Cosmochim. Acta 40, 323-330.

Illich H. A. and Grizzle P. L. (1983) Comment on "Comparison of Michigan Basin crude oils" by Vogler et al. Geochim. Cosmochim. Acta 47, 1157-1159.

Jonathan D., L'Hôte G. and du Rouchet J. (1985) Analyse géochimique des hydrocarbures légers par thermovaporisation. Rev. Inst. Fr. Pét. 30, 65-88.

Kannenberg E., Blume A. and Poralla K. (1984) Properties of $\omega$-cyclohexane fatty acids in membranes. FEBS Lett. 172, 331-334.

Lewan M. D. (1983) Effects of thermal maturation on stable organic carbon isotopes as determined by hydrous pyrolysis of Woodford shale. Geochim. Cosmochim. Acta 47, 1471-1479.

Labo J., Cousins J., Werner W. G. and Pan P. H. (1981) Exploring for Silurian-Niagaran pinnacle reefs in the southern Michigan Basin. Oil Gas J. 79(25), 93-98.

Mackenzie A. S. and McKenzie D. P. (1983) Isomerization and aromatization of hydrocarbons in sedimentary basins formed by extension. Geol. Mag. 120, 417-470.

Mackenzie A. S., Hoffmann C. F. and Maxwell J. R. (1981) Molecular parameters of maturation in the Toarcian shales, Paris Basin, France-III. Changes in aromatic steroid hydrocarbons. Geochim. Cosmochim. Acta 48, 1345-1355. 
Mackenzie A. S., Rullkötter J., Welte D. H. and Mankiewicz P. (1986) Reconstruction of oil formation and accumulation in North Slope, Alaska, using quantitative gas chromatography-mass spectrometry. In Alaska North Slope Oil-Rock Correlation Study (Edited by Magoon L. B. and Claypool G. E.). AAPG Studies in Geology Series No. 20, pp. 319-372. Am. Assoc. Pet. Geol., Tulsa.

Martin R. L., Winters J. C. and William J. A. (1963) Distribution of $n$-paraffins in crude oils and their implication to origin of petroleum. Nature, London 199, 110-113.

McKirdy D. M., Aldridge A. K. and Ypma P. J. M. (1983) A geochemical comparison of some crude oils from pre-Ordovician carbonate rocks. In Advances in Organic Geochemistry 1981 (Edited by Bjorøy M. et al.), pp. 99-107. Wiley, Chichester.

McMullan R. A. and Slaughter A. E. (1964) Stratigraphic succession in Michigan. Michigan Department of Natural Resources.

Meyers P. A. and Moore W. E. (1983) Comparison of Michigan Basin crude oils (reply to comments by Illich and Grizzle and by Pruitt). Geochim. Cosmochim. Acta 47, $1161-1162$.

Mold J. D., Means R. E. and Ruth J. M. (1966) The higher fatty acids of flue-cured tobacco. Methyl and cyclohexyl branched acids. Phytochemistry 5, 59-66.

Momper J. A. (1978) Oil migration limitations suggested by geological and geochemical considerations. In Physical and Chemical Constraints on Petroleum Migration (Edited by Roberts W. H., III and Cordell R. J.). AAPG Continuing Education Course Note Series No. 8, pp. B-1-B60. Am. Assoc. Pet. Geol., Tulsa.

Nunn J. A. and Sleep N. H. (1978) Thermal contraction and petroleum maturation in Michigan Basin. $A A P G$ Abstracts of Papers, pp. 99-100.

Nunn J. A. and Sleep N. H. (1984) Thermal contraction and flexure of intracratonal basins: a three-dimensional study of the Michigan Basin. Geophys. J. R. Astron. Soc. 76, $587-635$

Nunn J. A., Sleep N. H. and Moore W. E. (1984) Thermal subsidence and generation of hydrocarbon in Michigan Basin. Bull. Am. Assoc. Pet. Geol. 68, 296-315.

Nunn J. A., Sleep N. H. and Moore W. E. (1985) Thermal subsidence and generation of hydrocarbons in Michigan Basin: Reply. Bull. Am. Assoc. Pet. Geol. 69, 1185-1187.

Oshima M., Sakaki Y. and Oshima T. (1978) $\omega$-Cyclohexyl fatty acids in acido-thermophilic bacterial membranes and phage capsids. In Biochemistry of Thermophily (Edited by Friedman S. M.), pp. 31-44. Academic Press, New York.

Philp R. P. and Gilbert T. D. (1982) Unusual distribution of biological markers in an Australian crude oil. Nature, London 299, 245-247.

Powell T. G., Macqueen R. W., Barker J. F. and Bree D. G. (1984) Geochemical character and origin of Ontario oils. Bull. Can. Soc. Pet. Geol. 32, 289-312.

Pruitt J. D. (1983) Comment on "Comparison of Michigan Basin crude oils". Geochim. Cosmochim. Acta 47, 1159-1161.

Radke M. and Welte D. H. (1983) The Methylphenanthrene Index (MPI): a maturity parameter based on aromatic hydrocarbons. In Advances in Organic Geochemistry 1981 (Edited by Bjorry M. et al.), pp. 504-512. Wiley, Chichester.

Radke M., Willsch H. and Welte D. H. (1980) Preparative hydrocarbon group type determination by automated medium pressure liquid chromatography. Anal. Chem. 52 , 406-411.

Radke M., Welte D. H. and Willsch H. (1982) Geochemical study on a well in the Western Canada Basin: relation of the aromatic distribution pattern to maturity of organic matter. Geochim. Cosmochim. Acta 46, 1-10.

Radke M., Leythaeuser D. and Teichmüller M. (1984) Relationship between rank and composition of aromatic hydrocarbons for coals of different origin. In Advances in Organic Geochemistry 1983 (Edited by Schenck P. A., de Leeuw J. W. and Lijmbach G. W. M.). Org. Geochem. 6, 423-430. Pergamon Press, Oxford.

Reed J. D., Illich H. A. and Horsfield B. (1986) Biochemical evolutionary significance of Ordovician oils and their sources. In Advances in Organic Geochemistry 1985 (Edited by Leythaeuser D. and Rullkötter J.), pp. 347-358. Pergamon Journals, Oxford.

Risatti J. B., Rowland S. J., Yon D. A. and Maxwell J. M. (1984) Stereochemical studies of acyclic isoprenoids-XII. Lipids of methanogenic bacteria and possible contribution to sediments. In Advances in Organic Geochemistry 1983 (Edited by Schenck P. A., de Leeuw J. W. and Lijmbach G. W. M.). Org. Geochem. 6, 93-104. Pergamon Press, Oxford.

Rubinstein I. and Strausz O. P. (1979) Geochemistry of the thiourea adduct fraction from an Alberta petroleum. Geochim. Cosmochim. Acta 43, 1387-1392.

Rullkötter J. and Philp R. P. (1981) Extended hopanes up to $\mathrm{C}_{40}$ in Thornton bitumen. Nature, London 292, 616-618.

Rullkötter J., Spiro B. and Nissenbaum A. (1985) Biological marker characteristics of oils and asphalts from carbonate source rocks in a rapidly subsiding graben, Dead Sea, Israel. Geochim. Cosmochim. Acta 49, 1357-1370.

Rullkötter J., Mackenzie A. S., Welte D. H., Leythauser D. and Radke M. (1984) Quantitative gas chromatographymass spectrometry analysis of geological samples. In Advances in Organic Geochemistry 1983 (Edited by Schenck P. A., de Leeuw J. W. and Lijmbach G. W. M.). Org. Geochem. 6, 817-827. Pergamon Press, Oxford.

Schaefer R. G., Weiner B. and Leythaeuser D. (1978) Determination of sub-nanogram per gram quantities of light hydrocarbons $\left(\mathrm{C}_{2}-\mathrm{C}_{9}\right)$ in rock samples by hydrogen stripping in the flow system of a capillary gas chromatograph. Anal. Chem. 50, 1848-1854.

Schaefer R. G., Welte D. H. and Pooch H. (1984) Geochemistry of low molecular weight hydrocarbons in two exploration wells in the Elmworth gas field (Western Canada Basin). In Advances in Organic Geochemistry 1983 (Edited by Schenck P. A., de Leeuw J. W. and Lijmbach G. W. M.). Org. Geochem. 6, 695-70l. Pergamon Press, Oxford.

Sieskind O., Joly G. and Albrecht P. (1979) Simulation of the geochemical transformation of sterols: superacid effect of clay minerals. Geochim. Cosmochim. Acta 43, 1675-1679.

Sleep N. H. and Sloss L. L. (1978) A deep borehole in the Michigan Basin. J. Geophys. Res. 83, 5815-5819.

Sofer Z. (1984) Stable carbon isotope composition of crude oils: Application to source depositional environments and petroleum alteration. Bull. Am. Assoc. Pet. Geol. 68, $31-49$.

Stahl W. J. (1980) Compositional changes and ${ }^{13} \mathrm{C} /{ }^{12} \mathrm{C}$ fractionation during the degradation of hydrocarbons by bacteria. Geochim. Cosmochim. Acta 44, 1903-1907.

Thompson K. F. M. (1979) Light hydrocarbons in subsurface sediments. Geochim. Cosmochim. Acta 43, 457-672.

Vogler E. A., Meyers P. A. and Moore W. E. (1981) Comparison of Michigan Basin crude oils. Geochim. Cosmochim. Acta 45, 2287-2293.

Zumberge J. E. (1983) Tricyclic diterpane distributions in the correlation of Palaeozoic crude oils from the Williston Basin. In Advances in Organic Geochemistry 1981 (Edited by $M$. Bjorøy et al.), pp. 738-745. Wiley, Chichester. 